\title{
The Role of Language Centers in Jordanian Universities in Spreading a Culture of Cultural Diversity among their Students
}

\author{
Arwa Khalil Al-Maayta Prof. Dr. Mohammad Saleem Al-Zboon \\ University of Jordan
}

\begin{abstract}
The study aimed to identify the role of language centers in Jordanian universities in spreading a culture of cultural diversity among their students. To achieve the objectives of the study, the survey approach was used to suit the nature of this study, where a questionnaire was designed and distributed to a 400 -student sample from Jordanian universities. The results of the study showed that the role of language centers in Jordanian universities in spreading the culture of cultural diversity among their students from the viewpoint of the study sample was at a low level in general, where the field of cultural diversity principles among the faculty members and the field of cultural diversity principles in the field of academic course books ranked first. As for the principles of cultural diversity in the field of university activities, they ranked last. The results showed that there were no statistically significant differences in the study sample estimations of the role of language centers in Jordanian universities in spreading a culture of cultural diversity among their students due to gender and nationality variables.
\end{abstract}

Keywords: Language centers, Jordan, diversity, university students.

DOI: $10.7176 / \mathrm{JEP} / 11-6-06$

Publication date: February $29^{\text {th }} 2020$

\subsection{Introduction}

The world has recently witnessed a great development in the means of communication and connection, which resulted in numerous exchanges and mixing between different cultures and this is precisely what is known as cultural diversity. Cultural diversity is a natural phenomenon and a fundamental feature in modern human societies. The subject of cultural diversity has generally received the attention of researchers and related organizations as a heritage of all humanity, which forms the firm foundation which societies depend on to achieve their goals by providing individuals with sources of positive change and creativity. The study of cultural diversity holds a great level of significance due to the role it plays in transferring societies to advanced levels of awareness of the capabilities and skills of others that must be used properly and effectively that enriches the experience of societies and individuals alike (Falouh and Zboun, 2018).

Since God created the universe, the difference and human and cultural diversity in the world have not been a cause of disagreement, discord, conflict, and war. God did not create this diversity in vain, but for the acquaintance, rapprochement and cooperation for the sake of human happiness, not their misery. This is known as sustainable development or reconstruction of the earth, and an affirmation of the meaning of creative human diversity, which means dialogue among equitable parties, interdependence between peoples and nations, and positive interaction between beliefs and doctrines to achieve the desired development for the welfare of human beings and build a new world in which meanings of tolerance, right of opinion, and respect for others. The UNESCO General Conference, in commemoration of the World Day for Cultural Diversity, Dialogue, and Human Development, adopted awareness-raising programs and mechanisms to enhance the concept of cultural diversity and work to remove obstacles that hinder the achievement of cultural and human dialogue and the required integration among the elements and races of human societies (United Nation Organization, 2002).

Therefore, the cultural interaction with other cultures opened the door for the establishment of civilizational coexistence centers for many international cultures, including the language centers in the Jordanian universities combined to create a fertile environment in which the process of give and take, all on the ground of cultural coexistence, which is a major pillar for the unification of nations and societies and a basic interface to confront terrorism in all its forms and manifestations and build an friendly environment for security, peace, and respect for the other.

Cultural diversity is a significant civilizational principle that has the greatest role in bringing ideas and distances closer and weaving bonds of understanding and between nations and peoples. It aims to bring different cultures and civilizations closer together and make them open to each other in a relentless pursuit of distinct accord and harmony and, beneficial understanding that allows recognition of pluralism, cultural diversity, and recognition of the other elements of cultural production and civilization creativity (Azouzi, 2012). Cultural diversity has become one of the most important features that societies must realize its importance because it affects all aspects of life. Societies also must realize that diversity has become a necessity and not a point of dispute as it was in the past, noting that this diversity has become part of the culture of societies (Bikay, 2015).

In light of the challenges and changes affected all aspects of life, students need to acquire the knowledge and skills necessary to be active citizens in the human community. In detail, whenever educational institutions focus 
on teaching and exercising freedom in their environment and experimental educational space, they produce a conscious learner of the importance of democracy and respect for other cultures and lack of intolerance, along with having active participation within the local and global environment. The concepts of freedom and citizenship based on identity create citizens who believe in respect of multiculturalism, reject racial discrimination, and can interact with those who have backgrounds different from their background and ethnicity (Kiwan, 2008).

Among these institutions are language centers that have a major role in deepening the concepts of respecting the culture of cultural diversity, and which have tasks related to achieving the goals of society, such as spreading awareness and solving problems, promoting a culture of dialogue and emphasizing positive values that benefit the individual and society. The university's fulfillment of these tasks is the outcome of all other jobs, and that its success in education and practical research is highly dependent on the university's success in its social function. Thus, it occupies the forefront as an institution concerned with developing citizenship at its local and global dimensions and respecting cultural diversity and creating appropriate conditions for its development (Jayyar, 2007).

Language centers in Jordanian universities look to be distinguished and active centers at the local and global levels in the field of promoting a culture of respect for diversity and cultural coexistence among its various students. They also emphasize the importance of developing and expanding cooperation with leading institutions in the field of academic and practical work to achieve the center's goals, to build the new ideal qualified and trained person to learn about the cultures of other peoples and nations through communication with native speakers of their different languages.

From the above, it can be said that effective education offered in universities can achieve a safer, healthier and more prosperous world, as it contributes effectively to social, economic and cultural progress and contributes to deepening the concepts of understanding, respect for the last and respect for cultural diversity among nations. Against this, the problem of the study is to examine the role of Language centers in Jordanian universities in spreading the culture of cultural diversity among their students.

\subsection{Problem of the Study}

University education is considered one of the most important educational stages after school education, which makes it an important stage in preparing individuals to integrate into the social framework and achieve coexistence and harmony among its members. This stage is also a turning point for students in thinking and perception, which is an obstacle to achieving harmony and familiarity with the presence of many from the nationalities and identities that learn in foreign language centers. Thus, the contents of this diversity in this diverse fabric must be reformulated so that this does not hinder the trend of progress, growth, and prosperity.

Through the work of a researcher as a lecturer at the Language Center in teaching and interacting with students of different cultures, it is seen that the group of students studying at the Language Center constitutes a cultural wealth that can be used as a credit that enriches the culture of society.

Hence, the importance of language centers, which are among the most important parts and channels of other nationalities and cultures, due to the effective role of language centers in Jordanian universities in spreading the culture of cultural diversity. Accordingly, the problem of the study is formatted to explore the role of language centers in Jordanian universities in spreading the culture of cultural diversity among its students.

\subsection{Questions of the Study}

In light of the problem of the study, the following questions have been articulated:

1. What is the role of language centers in Jordanian universities in spreading a culture of cultural diversity among their students from the students' viewpoint themselves?

2. Are there statistically significant differences at $(\alpha=0.05)$ between the arithmetic means of the study sample estimations for the role played by the language centers in Jordanian universities in spreading a culture of cultural diversity according to gender and nationality variables?

\subsection{Objectives of the Study}

The following objectives are formatted to answer the aforesaid questions.

This study aims to explore the role of language centers in Jordanian universities to spread the culture of cultural diversity among its students and its relationship to some variables from the students' standpoint themselves.

\subsection{Significance of the Study}

The significance of the study lies in its expected results, as it is hoped that several authorities will benefit from the results of the study such as the Ministry of Higher Education in terms of setting educational policies that ensure achieving sustainable development in Jordanian universities through benefitting from the human potential represented by language center students in Jordanian universities and reviewing the systems and laws of higher education. Jordanian universities can also use this study by increasing the effectiveness of faculty members, and developing their teaching performance to carry out academic, scientific, and community service roles and 
activating their roles to benefit from cultural diversity. Also, it helps instructors by educating them about the importance of respecting cultural diversity and its role in the processes of development. Besides, researchers and those interested in this field can use this study by opening the door for researchers and those interested in conducting and developing studies in the same field.

\subsection{Previous Studies}

The subject of the study has been addressed by several studies such as the study 2013 of Jeannine that aimed to determine students' perceptions of cultural diversity in the classroom at an international university in Bangkok, Kingdom of Thailand to better understand students' experience about cultural diversity at the university and better meet their learning needs. To achieve the objective of the study, questionnaires were distributed to (242) male and female students from (52) different nationalities. The study concluded that students prefer to join various classes to improve their abilities in the English language and to experience learning in culturally multiple classes and that the difference in language is what most concerns students in studying at the university. This study indicated that (94\%) of students consider diversity a positive opportunity for them.

In their 2017 study, Leen, Dunn, \& Forrest (2017) aimed at knowing the attitudes of classroom teachers towards cultural diversity in New South Wales in Australia. The study adopted the descriptive approach and used the state-level questionnaire, as it was sent online to 55 thousand teachers and executive staff in the public schools in the state. The response rate was $10 \%$, i.e. 688 individuals who received the e-mail and filled out the questionnaire. The results of the study concluded that there is a difference in attitudes among teachers towards multicultural values and that loyal attitudes to multiculturalism are in the least powerful, as they were areas with the greatest diversity, especially in areas with the highest percentage of the indigenous population.

Likewise, in their 2017 study, Enyeart, Wessel, \& Polacek aimed to identify the views of university students and postgraduate students at the Department of Academic Health Professions about cultural diversity and cultural acceptance at Stoma University in Australia. With that, they used the questionnaire and descriptive approach. The study reached many results, namely: responses and attitudes of students towards management are unanimous that management is based on modeling cultural competencies, addressing diversity in school curricula and increasing knowledge of cultural diversity. Importantly, the previous studies have been used to direct the current study towards the optimal way in selecting the data collection and analysis tool using the appropriate statistical methods and treatments. The most important thing that distinguishes this study from the previous relevant studies that were mentioned in this study is that it examined the role of language centers in Jordanian universities to spread the culture of cultural diversity among its students.

\subsection{Methodology of the Study}

This study aims to examine the role of language centers in Jordanian universities to spread the culture of cultural diversity among its students. To achieve this objective, the survey method has been used.

\section{Operational Definitions of the Study}

Several operational definitions have been adopted as follows:

Cultural diversity: diversity is defined as the differences that exist among individuals in terms of backgrounds represented by gender, age, physical and mental abilities, social class, race, education, culture, religion, customs, beliefs, etc. (Nadine, 2017). Hence, cultural diversity primarily means there are disparities between individuals in terms of cultural components.

\section{Study Population}

The study population consisted of all students of language centers at Jordanian universities.

\section{The Study Sample}

As for the study sample, it has been selected according to the random sample method, which gives each individual in the study population equal opportunities. The number of the sample population was (400) male and female students from Jordanian university students as shown in Table (1).

Table 1: Frequencies and Percentages According to the Study Variables

\begin{tabular}{|l|l|l|l|}
\hline & Categories & Frequencies & Percentages \\
\hline \multirow{3}{*}{ Gender } & Male & 124 & 31.0 \\
\cline { 2 - 4 } & Female & 276 & 69.0 \\
\hline & Foreign & 78 & 19.5 \\
\cline { 2 - 4 } & Arab & 78 & 19.5 \\
\cline { 2 - 4 } & Local & 244 & 61.0 \\
\hline & Total & 400 & 100.0 \\
\hline
\end{tabular}

\section{Study Instrument}

To achieve the aims of the study, theoretical literature and previous studies that dealt with cultural diversity such as the study of Falouh and Zboun (2018) and other related studies have been comprehensively addressed. 


\section{Instrument Validity}

To verify the validity of the content of the study instrument, the content validity was used by presenting it to a group of validators and specialists in Jordanian universities to express their views in the questionnaire items in terms of clarity of meaning, linguistic formulation, the degree of their suitability for the related field, and any modifications and notes they see appropriate. Of note, $80 \%$ of the observations of the validators have been strongly adopted to achieve the objectives of the study.

\section{Instrument Reliability}

To verify the reliability of the study instrument, it was rechecked by using the test-retest method, and the reliability coefficient was calculated by the internal consistency method according to Cronbach's alpha formula. Table (2) shows the internal consistency method according to Cronbach's alpha formula and the reliability of the return for the fields and the instrument as a whole. Of note, these values were considered appropriate for this study.

Table 2: The Internal Consistency Coefficient of the Cronbach Alpha, the Reliability Return of the Fields and the Total Score

\begin{tabular}{|l|l|l|}
\hline Field & Reliability Return & Signature \\
\hline Principles of cultural diversity among the faculty members & 0.85 & 0.72 \\
\hline Principles of cultural diversity in the field of curricula & $\mathbf{0 . 9 5}$ & $\mathbf{0 . 7 3}$ \\
\hline Principles of cultural diversity in the field of university activities & $\mathbf{0 . 8 8}$ & $\mathbf{0 . 8 2}$ \\
\hline Total Degree & $\mathbf{0 . 9 0}$ & \\
\hline
\end{tabular}

The criterion for judging the means of the study instrument was determined by dividing it into three degrees: low, medium, and high, according to the following formula:

Category Length $=$ Highest value of the substitute - The minimum value of the substitute / Number of levels

$$
=(5-1) / 3=1.33
$$

Accordingly, the following criterion was used to judge the responses of the study sample:

Low degree is less than 2.33 .

Medium degree is 2.34 to 3.67 .

High degree from 3.68 to 5.00

\section{Results and Discussion}

The first question: "What is the role of language centers in Jordanian universities in spreading a culture of cultural diversity among their students from the students' viewpoint themselves?

To answer this question, means and standard deviations were calculated as shown in Table (3)

Table 3: Arithmetic Means and Standard Deviations for the Role of Language Centers in Jordanian Universities in Spreading a Culture of Cultural Diversity from the Students' Viewpoint Themselves in Descending Order According to Arithmetic Means

\begin{tabular}{|l|l|l|l|l|l|}
\hline Rank & No & Item & AM & SD & Level \\
\hline 1 & 1 & Principles of cultural diversity among the faculty members & 2.31 & .406 & Low \\
\hline 2 & 2 & Principles of cultural diversity in the field of curricula & 2.31 & .487 & Low \\
\hline 3 & 3 & Principles of cultural diversity in the field of university activities & 2.27 & .556 & Low \\
\hline & & Total degree & 2.30 & .390 & Low \\
\hline
\end{tabular}

Table (3) shows that the arithmetic means ranged between (2.27-2.31), where the principles of cultural diversity among faculty members and the principles of cultural diversity in the field of academic courses ranked first with the highest arithmetic mean of (2.31). However, the principles of cultural diversity in the field of university activities ranked last with an arithmetic mean of (2.27), and the average degree for the total degree is (2.30). The arithmetic means and standard deviations for the estimations of the study sample individuals were calculated on the items of each axis separately as follows: 
The First Axis: the Principles of Cultural Diversity among the Faculty Members

Table 4: Arithmetic Means and Standard Deviations Related to the Principles of Cultural Diversity among Faculty Members are in Descending Order According to the Arithmetic Mean

\begin{tabular}{|c|c|c|c|c|c|}
\hline Rank & No & Item & AM & SD & Level \\
\hline 1 & 20 & $\begin{array}{l}\text { Educational materials on cultural coexistence issues are offered as an } \\
\text { art of community management. }\end{array}$ & 2.78 & 1.363 & Medium \\
\hline 2 & 14 & $\begin{array}{l}\text { The faculty member promotes relationships between multicultural } \\
\text { students. }\end{array}$ & 2.76 & 1.328 & Medium \\
\hline 3 & 5 & $\begin{array}{l}\text { Some of the lectures are emptied to discuss some global issues to } \\
\text { understand them. }\end{array}$ & 2.70 & 1.398 & Medium \\
\hline 4 & 6 & $\begin{array}{l}\text { The faculty member provides us with a quarterly plan that includes } \\
\text { references related to cultural diversity issues. }\end{array}$ & 2.62 & 1.444 & Medium \\
\hline 5 & 4 & $\begin{array}{l}\text { The faculty member introduces students to human rights tools during } \\
\text { the teaching process. }\end{array}$ & 2.58 & 1.339 & Medium \\
\hline 6 & 2 & $\begin{array}{l}\text { The faculty members adopt the value system that deals with cultural } \\
\text { coexistence during teaching. }\end{array}$ & 2.57 & 1.330 & Medium \\
\hline 7 & 9 & $\begin{array}{l}\text { Students are introduced to cultural diversity ideas by introducing them } \\
\text { to other people's cultures. }\end{array}$ & 2.55 & 1.300 & Medium \\
\hline 8 & 15 & $\begin{array}{l}\text { A faculty member respects students regardless of their cultural } \\
\text { background. }\end{array}$ & 2.51 & 1.442 & Medium \\
\hline 9 & 8 & $\begin{array}{l}\text { A page is available on the university's e-learning website to enhance } \\
\text { the expression of opinion between the faculty member and his students. }\end{array}$ & 2.41 & 1.329 & Medium \\
\hline 10 & 12 & $\begin{array}{l}\text { The faculty member encourages acceptance of other cultures by } \\
\text { making sure to stick to the basic culture of his community. }\end{array}$ & 2.37 & 1.268 & Low \\
\hline 11 & 11 & Students are evaluated objectively without discrimination. & 2.30 & 1.351 & Low \\
\hline 12 & 17 & $\begin{array}{l}\text { The faculty knows that diversity is a universal moral ethical virtue with } \\
\text { a realistic human trait that benefits social mobility. }\end{array}$ & 2.29 & 1.176 & Low \\
\hline 13 & 3 & $\begin{array}{l}\text { The faculty member trains students on the global concepts mentioned } \\
\text { in the curricula. }\end{array}$ & 2.19 & 1.184 & Low \\
\hline 14 & 16 & $\begin{array}{l}\text { The faculty member bridges the gap of cultural differences between the } \\
\text { present and the future, reinforced by human visions in which everyone } \\
\text { shares without acquisition. }\end{array}$ & 2.17 & 1.192 & Low \\
\hline 15 & 13 & $\begin{array}{l}\text { The faculty member permits the exchange of views away from any } \\
\text { restrictions on freedom of expression. }\end{array}$ & 2.03 & 1.181 & Low \\
\hline 16 & 7 & $\begin{array}{l}\text { The faculty member submits a project to be discussed in the classroom, } \\
\text { which is related to developing the skill of dialogue that respects the } \\
\text { other opinion. }\end{array}$ & 2.01 & 1.108 & Low \\
\hline 17 & 19 & $\begin{array}{l}\text { Cultural diversity helps lay the groundwork for convergence on solid } \\
\text { foundations of mutual respect for noble human values. }\end{array}$ & 1.97 & 1.084 & Low \\
\hline 18 & 18 & $\begin{array}{l}\text { Cultural diversity is seen as a civilization imperative as an essential } \\
\text { tool for achieving social peace and harmony. }\end{array}$ & 1.90 & 1.039 & Low \\
\hline 19 & 1 & $\begin{array}{l}\text { A faculty member selects subjects during teaching that are in line with } \\
\text { undergraduate courses focused on cultural diversity. }\end{array}$ & 1.81 & .969 & Low \\
\hline \multirow[t]{2}{*}{20} & 10 & $\begin{array}{l}\text { The faculty member respects cultural particularities by creating a } \\
\text { logical basis within a medium that everyone can meet. }\end{array}$ & 1.76 & 1.089 & Low \\
\hline & & Principles of cultural diversity among the faculty members & 2.31 & .406 & Low \\
\hline
\end{tabular}

Table (4) shows that the arithmetic means ranged between (1.76-2.78), as item (20) states "Educational materials on cultural coexistence issues are offered as an art of community management" ranked first with an arithmetic mean of (2.78), while item No. (10) states "The faculty member respects cultural particularities by creating a logical basis within a medium that everyone can meet" ranked last with a mean of (1.76). The mean of the principles of cultural diversity among faculty members as a whole was (2.31).

In detail, this may be caused by students' awareness of the necessity of having a set of common characteristics among faculty members related to respecting the cultural and religious privacy of students, adopting a criterion for performance excellence when assessing students, believing in a culture of difference between societies and individuals, and viewing cultural diversity as something that should be encouraged while maintaining the basic culture of society, and believing in the importance of cultural diversity and the possibility of benefiting from it, especially in the field of novelties of scientific research, as well as the flexibility that faculty members must enjoy accepting the other opinion and listening to students. Alternatively, there are some personal differences between 
the faculty members in areas such as allowing participating in activities and conferences, accepting criticism with an open mind, combining the Arabic and foreign languages during education, and encouraging relations with students from other cultures, or distinguishing between students on the basis gender and origin.

Besides, this may be due to the awareness of the study sample that respecting the cultural diversity of students is one of the ethics that must be demonstrated by the faculty member, where ethics is one of the most important elements of human life, as it is the motive and driver of human behavior.

The Second Axis: the Principles of Cultural Diversity in the Field of Curricula

Table 5: Arithmetic Means and Standard Deviations Related to the Principles of Cultural Diversity in the Field of Curricula are in Descending Order According to the Arithmetic Mean

\begin{tabular}{|l|l|l|l|l|l|}
\hline Rank & No & Item & AM & SD & Level \\
\hline 1 & 6 & Introducing an optional cultural course dealing with global issues. & 2.89 & 1.511 & Medium \\
\hline 2 & 7 & $\begin{array}{l}\text { Incorporating concepts related to cultural diversity issues within } \\
\text { courses to support the idea of getting to know others. }\end{array}$ & 2.67 & 1.578 & Medium \\
\hline 3 & 4 & $\begin{array}{l}\text { Adding an English course for each discipline to develop the ability to } \\
\text { communicate with others. }\end{array}$ & 2.65 & 1.331 & Medium \\
\hline 4 & 1 & $\begin{array}{l}\text { Emphasizing cultural interests in the objectives of the courses to bring } \\
\text { nations together as a positive affair. }\end{array}$ & 2.50 & 1.328 & Medium \\
\hline 5 & 3 & $\begin{array}{l}\text { Providing scientific knowledge, whether it is in the human or scientific } \\
\text { fields by emphasizing its international character. }\end{array}$ & 2.37 & 1.217 & Medium \\
\hline 6 & 10 & $\begin{array}{l}\text { Using electronic communication in the academic curricula to confirm } \\
\text { the ideas of education for cultural diversity to be adopted in the } \\
\text { students' evaluation. }\end{array}$ & 2.32 & 1.237 & Low \\
\hline 7 & 5 & $\begin{array}{l}\text { Including human rights tools related to respecting others in courses } \\
\text { Development of the principles of democracy in dialogue through } \\
\text { academic courses. }\end{array}$ & 2.19 & 1.241 & Low \\
\hline 8 & 9 & $\begin{array}{l}\text { Using studies (local and international) to enhance the positive } \\
\text { dimension of cultural diversity. }\end{array}$ & 1.95 & 1.055 & Low \\
\hline 9 & 2 & $\begin{array}{l}\text { Introducing the goals of cultural diversity in the curricula to introduce } \\
\text { students to them. }\end{array}$ & 1.91 & 1.084 & Low \\
\hline 10 & 8 & $\begin{array}{l}\text { Developing the skill of positive dialogue through academic courses. } \\
\text { Principles of cultural diversity in the field of curricula }\end{array}$ & 2.90 & 1.058 & Low \\
\hline
\end{tabular}

Table (5) shows that the arithmetic means ranged between (1.90-2.89), as item (6) stated "Introducing an optional cultural course dealing with global issues" ranked first with a mean of (2.89), while item No. (8), which states "Developing the skill of positive dialogue through academic courses" ranked last with an arithmetic mean of (1.90). The mean of the principles of cultural diversity in the field of curricula as a whole was (2.31). This may be caused by the presence of the desire and awareness of students that universities should seek the help of experts and specialists in various fields when preparing study plans and academic courses to achieve the goal with the educational process. The curricula must contain topics interested in planting different cultures and dealing with global issues and to enhance the spirit of belonging among students. 
The Third Axis: the Principles of Cultural Diversity in the Field of University Activities

Table 6: Arithmetic Means and Standard Deviations Related to the Principles of Cultural Diversity in the Field of University Activities are in Descending Order According to the Arithmetic Mean

\begin{tabular}{|c|c|c|c|c|c|}
\hline Rank & No & Item & AM & SD & Level \\
\hline 1 & 2 & $\begin{array}{l}\text { Directing free activities for students to be oriented towards } \\
\text { globalization. }\end{array}$ & 2.84 & 1.486 & Medium \\
\hline 2 & 1 & $\begin{array}{l}\text { Students are encouraged to communicate with their peers through } \\
\text { group activities from other cultures. }\end{array}$ & 2.69 & 1.402 & Medium \\
\hline 3 & 11 & $\begin{array}{l}\text { Urging students to express the most important international issues by } \\
\text { drawing to express trends, including feelings. }\end{array}$ & 2.54 & 1.370 & Medium \\
\hline 4 & 10 & $\begin{array}{l}\text { Carrying out many activities dealing with the definition of different } \\
\text { cultures. }\end{array}$ & 2.49 & 1.294 & Medium \\
\hline 5 & 4 & Organizing student visits between universities to see other cultures. & 2.37 & 1.295 & Medium \\
\hline 6 & 8 & $\begin{array}{l}\text { Promoting university activities that entrench the values of cultural } \\
\text { diversity between countries. }\end{array}$ & 2.37 & 1.267 & Medium \\
\hline 7 & 7 & $\begin{array}{l}\text { Publishing research related to spreading the culture of education for } \\
\text { peace on websites to ensure exchange of experiences. }\end{array}$ & 2.34 & 1.258 & Medium \\
\hline 8 & 9 & $\begin{array}{l}\text { Proposing enhanced in-kind prizes for students engaged in outstanding } \\
\text { peace support activities. }\end{array}$ & 2.23 & 1.194 & Low \\
\hline 9 & 13 & Carrying out various cultural competitions to protect the environment. & 2.20 & 1.122 & Low \\
\hline 10 & 5 & Conducting competitions for activities that support peace concepts. & 2.13 & 1.179 & Low \\
\hline 11 & 15 & $\begin{array}{l}\text { Using billboards, including wall magazines to raise awareness of the } \\
\text { importance of communication leading to enhanced cultural } \\
\text { connectedness. }\end{array}$ & 2.01 & 1.163 & Low \\
\hline 12 & 3 & $\begin{array}{l}\text { Supporting university activities that contribute to understanding global } \\
\text { issues. }\end{array}$ & 1.99 & 1.134 & Low \\
\hline 13 & 14 & Utilizing university activities to improve intercultural communication. & 1.98 & 1.060 & Low \\
\hline 14 & 12 & $\begin{array}{l}\text { Organizing cultural exhibitions to introduce the cultures of different } \\
\text { peoples. }\end{array}$ & 1.96 & 1.132 & Low \\
\hline \multirow[t]{2}{*}{15} & 6 & Holding seminars that aim to introduce human rights. & 1.85 & 1.061 & Low \\
\hline & & & 2.27 & .556 & low \\
\hline
\end{tabular}

Table (6) shows that the arithmetic means ranged between (1.85-2.84) as item (2) stated "Directing free activities for students to be oriented towards globalization" ranked first with an arithmetic mean of (2.84), while item No. (6), which states "Holding seminars that aim to introduce human rights" ranked last with a mean of(1.85). The mean of the principles of cultural diversity in the field of university activities as a whole was (2.27). This may be caused by the students 'awareness of the importance of the role of student activities that a faculty member and university perform with students, as it increases the student's sense of belonging to this system. Therefore, universities should encourage students to participate in university activities such as theater clubs, book clubs, and various activities because this enhances one aspect of spreading a culture of cultural diversity and making them acquire a set of positive values, customs, and traditions able to contribute to their development.

Second Question: Are there statistically significant differences at $(\alpha=0.05)$ between the arithmetic means of the study sample estimations for the role played by the language centers in Jordanian universities in spreading a culture of cultural diversity according to gender and nationality variables?

To answer this question, arithmetic means and standard deviations were calculated for the role played by the language centers in Jordanian universities in spreading the culture of cultural diversity according to the variables of gender, nationality as shown in (7)

Table 7: Mathematical Means and Standard Deviations for the Role of Language Centers in Jordanian Universities in Spreading a Culture of Cultural Diversity by Gender and Nationality Variables

\begin{tabular}{|l|l|l|l|l|}
\hline \multirow{2}{*}{ Gender } & & AM & SD & NO \\
\hline \multirow{3}{*}{ Nationality } & Male & 2.31 & .378 & 124 \\
\cline { 2 - 5 } & Female & 2.29 & .396 & 276 \\
\cline { 2 - 5 } & Foreign & 2.30 & .458 & 78 \\
\cline { 2 - 5 } & Arab & 2.37 & .382 & 78 \\
\cline { 2 - 5 } & Local & 2.27 & .366 & 244 \\
\hline
\end{tabular}

Table (7) shows an apparent variation in arithmetic means and standard deviations of the role played by the language centers in Jordanian universities in spreading a culture of cultural diversity based on the principles of sustainable development due to the difference in the categories of gender and nationality variables. To indicate the significance of the statistical differences among the arithmetic means, binary variance analysis was used as shown 
in Table (8)

Table 8: Analysis of the Binary Variation of the Impact of Gender and Nationality on the Role Played by Language Centers in Jordanian Universities in Spreading a Culture of Cultural Diversity

\begin{tabular}{|l|l|l|l|l|l|}
\hline $\begin{array}{l}\text { Source of } \\
\text { Variance }\end{array}$ & Sum of squares & $\begin{array}{l}\text { Degrees of } \\
\text { Freedom }\end{array}$ & $\begin{array}{l}\text { Average of } \\
\text { Squares }\end{array}$ & Value of F & $\begin{array}{l}\text { Statistical } \\
\text { Significance }\end{array}$ \\
\hline Gender & .054 & 1 & .054 & .356 & .551 \\
\hline Nationality & .593 & 2 & .297 & 1.959 & .142 \\
\hline Error & 59.973 & 396 & .151 & & \\
\hline Total & 60.614 & 399 & & & \\
\hline
\end{tabular}

Table (8) shows that there are no statistically significant differences at the level of $(\alpha=0.05)$ due to the effect of gender, as the value of $F$ was 0.356 with a t statistical significance of 0.551 . It also shows that statistically significant differences are absent at $(\alpha=0.05)$ due to the impact of nationality, as the value of $F$ was 1.959 with a statistical significance of 0.142 . This result means that males and females do not differ and their nationalities do not differ in their estimation of the role of language centers in Jordanian universities in spreading a culture of cultural diversity among them, as they all of them learn in similar environments, which are Jordanian universities. In detail, this may be due to the awareness of students, regardless of their gender and nationality, of the importance of learning about other cultures in society and other countries in terms of their customs, traditions, and values, recognition of the legitimacy of other cultures in society as an integral part of society and mutual respect between cultures to develop self-criticism and self-realization of the individual in society and culture and give a new opportunity to ensure and achieve freedom and equality between different cultures in society, such as the enactment of laws to protect this diversity and respect.

\section{Recommendations}

In light of the above mentioned results, the following has been recommended:

1. Working on holding training courses capable of increasing the contribution of faculty members in Jordanian universities in activating language centers in spreading the culture of cultural diversity among students with a focus on increasing their awareness of the importance of this role.

2. Organizing professional development programs for faculty members to inform them of the principles of cultural diversity and the mechanisms for their development.

3. Conducting future studies that address the role of universities in spreading cultural diversity from the viewpoint of faculty and teachers

\section{References}

United Nations Educational, Scientific and Cultural Organization (2002, UNESCO)

Azouzi, Hassan Bin Idris. (2012). Protecting cultural diversity and identity from an Islamic perspective. Ministry of Endowments and Islamic Affairs, 2, 16-18.

Bikay, Abdul Majeed. (2015). Cultural diversity and its relationship to organizational values within multinational organizations in Algeria: A field study at the Ophthalmology Hospital Friendship in Algeria - Cuba, Wilaya of Djelfa. Journal of Studies and Research, UniversitY, 2, 11-23.

Enyeart, S. Wessel, M. and Polacek, G. (2017), Perceptions of Cultural Competency and Acceptance among College Students: Implications for Diversity Awareness in Higher Education. ABNF Journal, 2, 25-33.

Falouh, Rawan and Zboun, Muhammad. (2018). Level of acceptance of faculty members at the University of Jordan for cultural diversity among students from the students' viewpoint themselves, Arab Journal of Quality Assurance of University Education, 11, 44-58. .

Jayyar, Samir. (2007). Education for Citizenship for University Students: A Comparative Study. Future of Arab Education Journal, 4, 47, 227-294.

Jeannine, L. (2013), Students perception of diversity in an international classroom, Higher Learning Research Communications, 3, 4, 6-22.

Kiwan, D. (2008). Citizenship Education in England at the Cross-Road? Four Models of Citizenship and their Implications for Ethnic and Peace.

Leen, J. Deen, G. and Forrest, K. (2017). Attitudes of Classroom Teachers to Cultural Diversity and Multicultural Education in Country New South Wales - Australia. Australian Journal of Teacher Education, 5, 17-34.

Nadine, S. (2017). Managing Cultural Diversity: The Case of Small \& Medium Tourism Enterprises (SMTE). European Scientific Journal (ESJ), 13, 562-574. 